\title{
Vibrio breoganii sp. nov., a non-motile, alginolytic, marine bacterium within the Vibrio halioticoli clade
}

Correspondence

Jesús L. Romalde jesus.romalde@usc.es

\author{
Roxana Beaz Hidalgo, ${ }^{1}$ Ilse Cleenwerck, ${ }^{2}$ Sabela Balboa, ${ }^{1}$ Susana Prado, ${ }^{1}$ \\ Paul De Vos ${ }^{2}$ and Jesús L. Romalde ${ }^{1}$
}

\begin{abstract}
${ }^{1}$ Departamento de Microbiología y Parasitología, Centro de Investigaciones Biológicas (CIBUS)Facultad de Biología, Universidad de Santiago de Compostela, 15782, Santiago de Compostela, Spain

${ }^{2}$ BCCM/LMG Bacteria Collection, Laboratory of Microbiology, Ghent University, Ghent, Belgium
\end{abstract}

During the last decade, the number of Vibrio species has increased rapidly. At present, there are more than 70 recognized Vibrio species. It is known that these fermentative bacteria constitute a high proportion of the heterotrophic bacteria associated with marine bivalves, especially oysters, mussels and clams (Kueh \& Chan, 1985; Pujalte et al., 1993; Gómez-León et al., 2005). Several Vibrio species can be pathogenic and are associated with disease outbreaks (Prado et al., 2005); therefore, accurate identification of these micro-organisms is important. The multilocus sequence analysis technique has greatly improved the taxonomy of strains belonging to the Vibrionaceae and many existing species have been assigned to specific groups. These groups are usually named after a representative species in the group, e.g. the splendidus, diazotrophicus, scophthalmi, fischeri, harveyi or halioticoli clades, among others (Thompson et al., 2007; Sawabe et al., 2007b). Species of the Vibrio halioticoli clade are found in

Abbreviation: AFLP, amplified fragment length polymorphism.

The GenBank/EMBL/DDBJ accession numbers determined in this study are available with the online version of this paper.

Differential phenotypic characteristics of the seven isolates of $V$. breoganii sp. nov. and phylogenetic trees based on concatenated rpoA, atpA and 16S rRNA gene sequences are available with the online version of this paper. association with ecological niches in the gut of Haliotis species and are alginolytic, non-motile, unflagellated and fermentative marine bacteria. The $V$. halioticoli clade consists at present of eight species: $V$. halioticoli, $V$. superstes, $V$. neonatus, V. ezurae, V. gallicus, V. comitans, $V$. inusitatus and $V$. rarus. $V$. halioticoli was first described by Sawabe et al. (1998). V. comitans, V. inusitatus and V. rarus were described more recently (Sawabe et al., 2007a). Strains of the $V$. halioticoli clade have been found all over the world, including Japan (Sawabe et al., 1995, 1998, 2002, 2004a, 2007a), Australia (Hayashi et al., 2003), South Africa (Sawabe et al., 2003) and France (Sawabe et al., 2004b). In this study, a group of seven isolates that were phylogenetically and phenotypically similar to species of the $V$. halioticoli clade was isolated from the microbiota of Spanish clams (Ruditapes philippinarum and Ruditapes decussatus) and shown to represent a novel species. This is the first time that isolates of this clade have been obtained from molluscs other than Haliotis species.

Seven isolates $\left[\mathrm{RD} 15.11^{\mathrm{T}}\left(=\right.\right.$ CECT $\left.7222^{\mathrm{T}}=\mathrm{LMG} 23858^{\mathrm{T}}\right)$, RD 2G5 (=CECT $7367=$ LMG 24484), VB 16.3, C5.5, RD 2B2, C 4.15 and CMJ 13.7] were obtained from cultured clams on the north-west coast of Spain (Galicia) during a 2 year survey from March 2004 to December 2005. Standard bacteriological procedures were employed for 
analysis of the clams (Prado et al., 2005). Briefly, groups of 15-20 clams, depending on size, were dissected aseptically and samples of hepatopancreas, mantle, gonad, gills and extrapalial fluid were collected. Homogenates were prepared by adding a volume of saline solution (SS, $0.85 \%$ ) to the weighed organ samples $(1: 1)$. Samples were diluted serially in SS, plated on marine agar (MA; Pronadisa) and thiosulphate-citrate-bile-sucrose agar (TCBS; Oxoid) and incubated at $23 \pm 1{ }^{\circ} \mathrm{C}$ for 10 days (MA) or $48 \mathrm{~h}$ (TCBS). Pure cultures of the different colony morphologies were recovered on MA.

The reference strains used, $V$. comitans LMG $23416^{\mathrm{T}}, V$. rarus LMG $23674^{\mathrm{T}}$, V. inusitatus LMG $23434^{\mathrm{T}}$, V. ezurae LMG $19970^{\mathrm{T}}$, V. neonatus LMG $19973^{\mathrm{T}}$, V. gallicus LMG $21330^{\mathrm{T}}$ and $V$. superstes $\mathrm{LMG} 21323^{\mathrm{T}}$, were obtained from the BCCM/LMG. All strains were cultured on MA at $25{ }^{\circ} \mathrm{C}$ for $24 \mathrm{~h}$. All cultures were maintained frozen at $-80{ }^{\circ} \mathrm{C}$ in marine broth (Pronadisa) supplemented with $15 \%(\mathrm{v} / \mathrm{v})$ glycerol.

Phenotypic characteristics were determined by standard methods and by using commercial miniaturized kits (API 50CH, API 20E and API ZYM; bioMérieux). API 50CH was used with slight modifications as reported previously (Prado, 2006). Briefly, bacterial suspensions were prepared in SS, adjusted to an $\mathrm{OD}_{580}$ of 1.0 and mixed with $\mathrm{ZOF}$ medium (Lemos et al., 1985) $(1: 10, \mathrm{v} / \mathrm{v})$ prior to inoculation of the galleries. Readings were taken at 24, 48, 96 and $120 \mathrm{~h}$ and after 6 days. Readings after 6 days incubation were used for comparison. For API 20E and API ZYM, standard methodologies were used except that the medium used for the bacterial suspension was SS. In all cases, incubation was done at $23 \pm 1{ }^{\circ} \mathrm{C}$. Routine phenotypic tests were performed following the methodologies described by Lemos et al. (1985), West et al. (1986), Romalde \& Toranzo (1991) and MacFaddin (1993). All media were supplemented with $1 \% \mathrm{NaCl}$ when required. The absence of any flagellar arrangement was determined after staining cells from cultures grown on MA by the method of Heimbrook et al. (1989).

The seven clam isolates examined in this study shared the main phenotypic and chemotaxonomic features of the genus Vibrio except for the absence of flagella (Farmer, 1992). The strains were facultatively anaerobic, non-motile, Gram-negative and oxidase-positive. They required salt for growth, grew on TCBS, were susceptible to the vibriostatic agent $\mathrm{O} / 129(150 \mu \mathrm{g}$ per disc) and reduced nitrates to nitrites. The seven isolates were phenotypically homogeneous in the tests performed except for 11 variable traits (see Supplementary Table S1, available in IJSEM Online).

Genomic DNA for sequencing was extracted as described previously (Prado et al., 2005). Amplification and sequencing of the $16 \mathrm{~S}$ rRNA gene was performed by using a GenomeLab DTCS-Quick Start kit (Beckman Coulter) (Prado et al., 2005). Amplification and sequencing of the housekeeping genes $r p o A, r e c A$ and atpA were performed according to Thompson et al. $(2004,2005,2007)$. For the reference strains, sequences were retrieved from GenBank/ EMBL; sequences that were unavailable were determined in this study. Sequence data analysis was performed with the DNASTAR Lasergene SEQMAN program. Sequences of the isolates were subjected to a BLAST search against the latest release of GenBank. Phylogenetic trees were constructed by using the neighbour-joining and maximum-parsimony algorithms (Tamura et al., 2007). Distance matrices were calculated by using Kimura's two-parameter correction and stability of the groupings was estimated by bootstrap analysis (1000 replicates) using the program MEGA version 4.0.

Phylogenetic analysis based on 16S rRNA gene sequences revealed that the seven isolates belonged to the Gammaproteobacteria. The isolates showed $>99 \% 16 \mathrm{~S}$ rRNA gene sequence similarity to each other and were related phylogenetically to species of the $V$. halioticoli clade (Fig. 1; Supplementary Figs S1 and S2, available in IJSEM Online). RD $15.11^{\mathrm{T}}$ showed $>98 \%$ 16S rRNA gene sequence similarity to the type strains of $V$. comitans (99.6\%), V. inusitatus (99.0\%), V. rarus (99.0\%), V. ezurae (98.8\%), $V$. halioticoli (98.6\%), $V$. superstes (98.7\%) and $V$. neonatus (97.7\%). Recently, sequencing of housekeeping genes has proven useful to determine phylogenetic relationships among micro-organisms. For the family Vibrionaceae, different loci, e.g. gapA, gyrB, $\operatorname{rec} A$, $r p o A, p y r H$, atpA and $d n a J$, have been studied in the search for a useful phylogenetic marker capable of delineating Vibrio species (Thompson et al., 2004, 2005, 2007; Sawabe et al., 2007b; Nhung et al., 2007). In the present study, fragments of the rpoA (931 bp), recA (613-713 bp) and atpA (1322 bp) genes were sequenced. According to Thompson et al. (2005), strains of the same species will have $\geqslant 98.0 \%$ rpoA and $\geqslant 94.0 \%$ recA gene sequence similarity. The similarities between the $r p o A$ gene sequence of $V$. breoganii RD $15.11^{\mathrm{T}}$ and the type strains of $V$. comitans and $V$. superstes were above the intraspecies limit; similarities with the other six related species were under the limit. For the recA gene sequences, all similarity values were under the intraspecies limit (Table 1). It was impossible to amplify the recA gene for the type strain of $V$. superstes and this sequence is not available in GenBank. Phylogenetic trees based on $r p o A, \quad r e c A$ and atpA gene sequences confirmed the allocation of the isolates to the $V$. halioticoli clade, enabled their differentiation from recognized species of this clade and revealed $V$. superstes and $V$. comitans as the nearest phylogenetic neighbours (Fig. 2).

Genomic DNA for amplified fragment length polymorphism (AFLP) analysis was extracted by using an Easy DNA kit (Invitrogen). AFLP analysis was performed as described previously (Thompson et al., 2001), except that dendrograms were constructed by using the DICE coefficients and the UPGMA algorithm. AFLP DNA fingerprinting grouped the isolates together and enabled them to be differentiated from recognized species of the $V$. halioticoli clade, as well as from other vibrios (Beaz Hidalgo et al., 2008). 


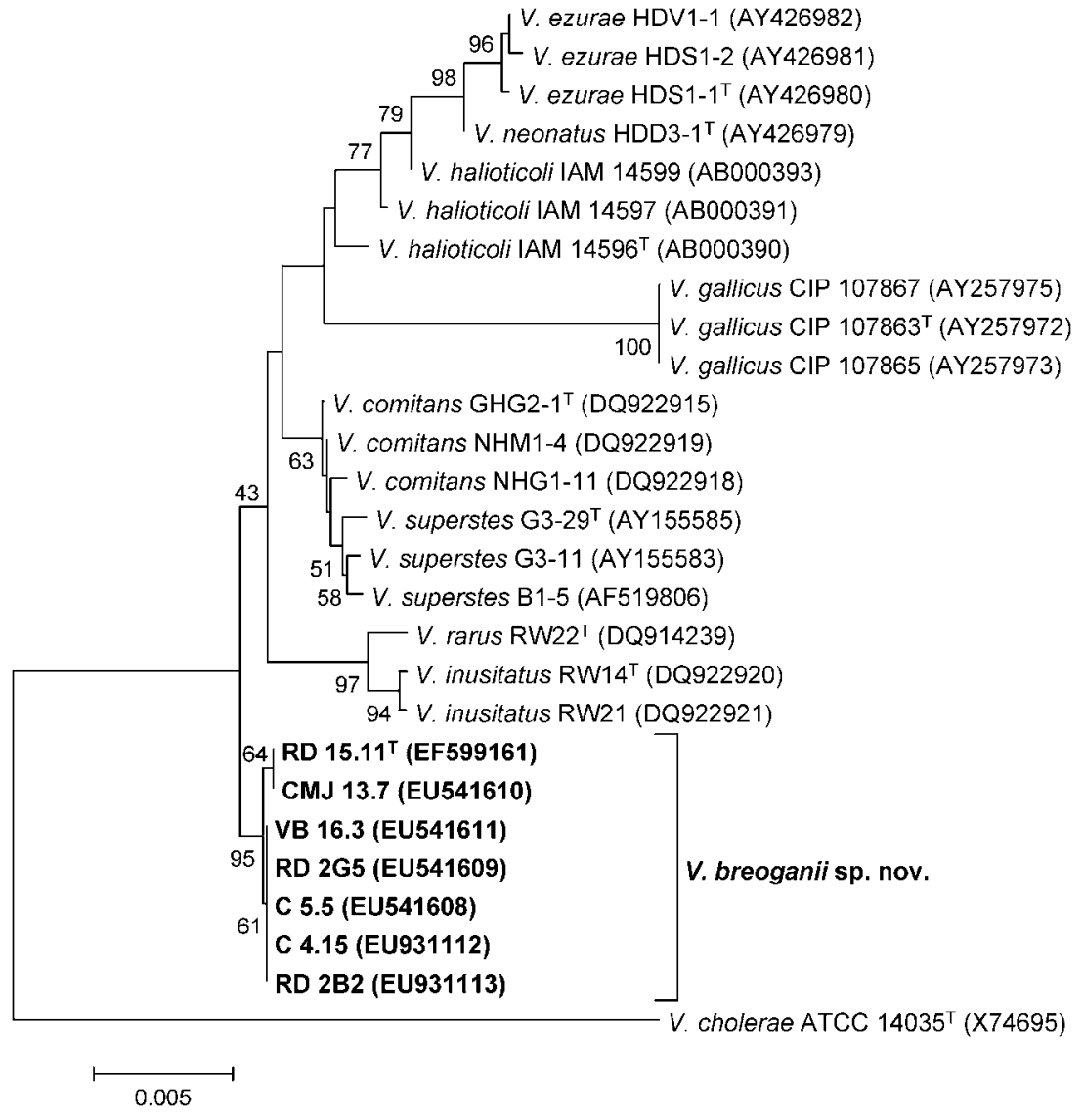

Fig. 1. Phylogenetic tree based on partial $16 \mathrm{~S}$ rRNA gene sequences using the neighbourjoining algorithm. Vibrio cholerae was used as outgroup. The stability of the groupings was estimated by bootstrap percentages from 1000 replicates. Similar results were obtained with the maximum-parsimony algorithm. Bar, 0.005 substitutions per nucleotide position.
Genomic DNA for DNA-DNA hybridizations and determination of the DNA $\mathrm{G}+\mathrm{C}$ content was prepared according to a modification (Cleenwerck et al., 2002) of the procedure of Wilson (1987). DNA-DNA hybridizations were performed at $39{ }^{\circ} \mathrm{C}$ according to a modification (Goris et al., 1998) of the method described by Ezaki et al. (1989). Reciprocal reactions (e.g. $\mathrm{A} \times \mathrm{B}$ and $\mathrm{B} \times \mathrm{A}$ ) were performed and were within the limits of this method (Goris et al., 1998). The DNA G $+\mathrm{C}$ content of RD $15.11^{\mathrm{T}}$ was determined by using the method of Mesbah et al.

Table 1. Sequence similarity values (\%) between the $16 \mathrm{~S}$ rRNA, $r e c A, r p o A$ and atp $A$ gene sequences of $V$. breoganii RD $15.11^{\top}$ and type strains of related Vibrio species

\begin{tabular}{|c|c|c|c|c|}
\hline Type strain & 16S rRNA & $\operatorname{rec} A$ & $r p o A$ & $\operatorname{atp} A$ \\
\hline V. comitans LMG $23416^{\mathrm{T}}$ & 99.4 & 93.0 & 99.8 & 97.4 \\
\hline V. inusitatus $\mathrm{LMG} 23434^{\mathrm{T}}$ & 99.0 & 91.0 & 96.0 & 97.2 \\
\hline V. rarus LMG $23674^{\mathrm{T}}$ & 99.1 & 84.0 & 94.0 & 93.0 \\
\hline$V$. superstes DSM $16383^{\mathrm{T}}$ & 98.2 & ND & 99.8 & 98.4 \\
\hline$V$. halioticoli IAM $14596^{\mathrm{T}}$ & 98.3 & 86.0 & 95.5 & 93.8 \\
\hline V. ezurae DSM $17533^{\mathrm{T}}$ & 97.6 & 86.6 & 95.7 & 94.4 \\
\hline V. neonatus DSM $17531^{\mathrm{T}}$ & 97.0 & 86.1 & 95.5 & 93.8 \\
\hline V. gallicus DSM $16639^{\mathrm{T}}$ & 97.5 & 82.0 & 92.0 & 88.5 \\
\hline
\end{tabular}

ND, Not done.
(1989). DNA of strain RD $15.11^{\mathrm{T}}$ was hybridized with DNA of the nearest phylogenetic neighbours; DNA-DNA relatedness values of RD $15.11^{\mathrm{T}}$ were $58 \%$ with $V$. superstes LMG $21323^{\mathrm{T}}$, $36 \%$ with $V$. comitans LMG $23416^{\mathrm{T}}, 28 \%$ with $V$. inusitatus LMG $23434^{\mathrm{T}}$, $19 \%$ with $V$. ezurae LMG $19970^{\mathrm{T}}$, $18 \%$ with $V$. neonatus LMG $19973^{\mathrm{T}}$, $15 \%$ with $V$. rarus $\mathrm{LMG} 23674^{\mathrm{T}}$ and $14 \%$ with $V$. halioticoli $\mathrm{LMG}$ $18542^{\mathrm{T}}$.

The novel isolates can be differentiated from phylogenetically related species by several features (Table 2). Strains can be differentiated from $V$. superstes by their ability to grow at $4{ }^{\circ} \mathrm{C}$ and in $6 \% \mathrm{NaCl}$, their positive reaction for the ONPG test and their inability to produce acid from trehalose. With the API ZYM methodology, other differences such as butyrate esterase (C4) and naphthol-AS-BIphosphohydrolase were found (data not shown). The novel isolates can be differentiated from $V$. inusitatus by their ability to produce acid from D-galactose and their positive reaction in the ONPG test. They can be differentiated from $V$. rarus by their ability to grow at $4{ }^{\circ} \mathrm{C}$, their positive reaction in the ONPG test, their ability to produce acid from amygdalin, D-xylose, D-galactose, aesculin and salicin, their inability to produce acid from glycerol and their negative reaction in the indole test. Additionally, the isolates showed a positive reaction in the API ZYM tests for esterase (C4), esterase lipase (C8), acid phosphatase and 
(a)

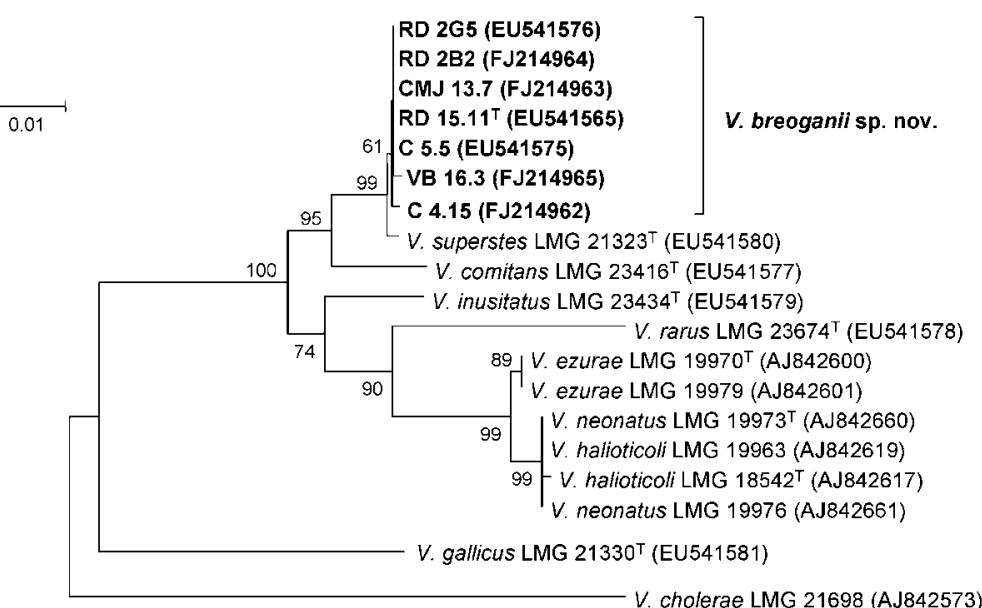

(b)

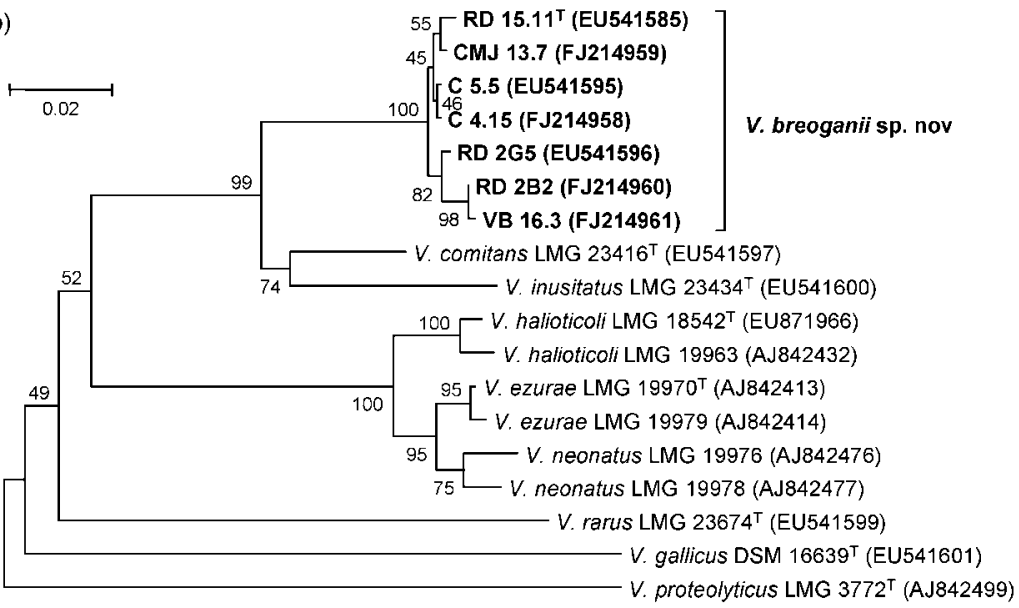

(c)

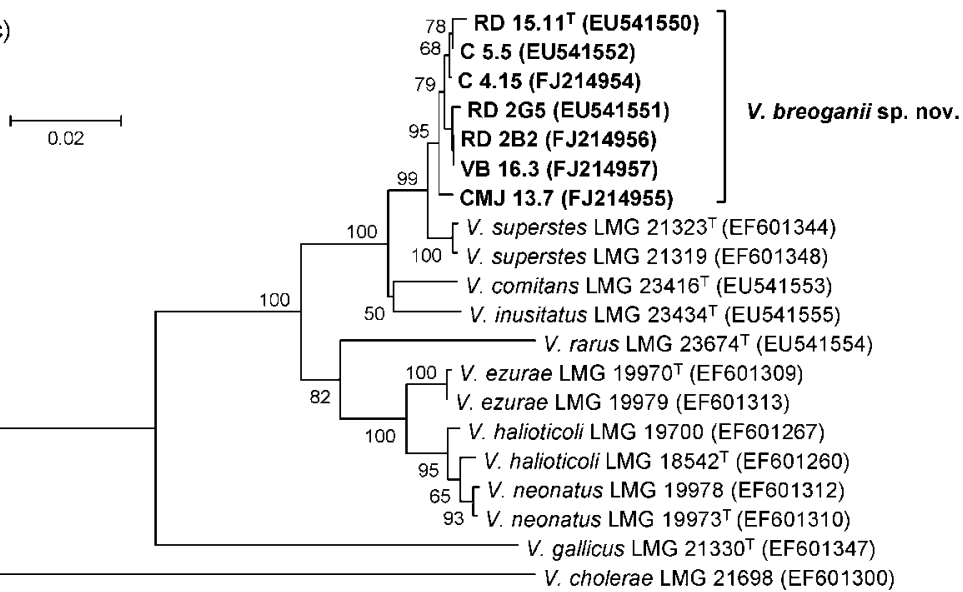

Fig. 2. Phylogenetic trees based on partial $\operatorname{rpo} A(\mathrm{a}), \operatorname{rec} A(\mathrm{~b})$ and $\operatorname{atp} A(\mathrm{c})$ sequences obtained by using the neighbour-joining algorithm. Vibrio cholerae or Vibrio proteolyticus was used as outgroup. The stability of the groupings was estimated by bootstrap percentages from 1000 replicates. Similar results were obtained employing the maximum-parsimony algorithm. Bars, no. of substitutions per nucleotide position.
naphthol-AS-BI-phosphohydrolase, in contrast to V. rarus, $V$. inusitatus and V. comitans.

In conclusion, the data presented above show clearly that the seven isolates belong to a novel species in the $V$. halioticoli clade. The name Vibrio breoganii sp. nov. is proposed for this novel species. The type strain is $\mathrm{RD}$ $15.11^{\mathrm{T}}\left(=\right.$ LMG $23858^{\mathrm{T}}=$ CECT $\left.7222^{\mathrm{T}}\right)$.

\section{Description of Vibrio breoganii sp. nov.}

Vibrio breoganii [bre.o.ga'ni.i. N.L. masc. gen. n. breoganii of Breogan, a mythical Celtic king of Galicia (north-west Spain), from where the strains were isolated].

Gram-negative, facultatively anaerobic, non-motile, nonflagellated rods $(0.5-0.75 \times 1.0-2.0 \mu \mathrm{m})$. Forms non-pigmented, translucent, non-swarming, round, smooth col- 
Table 2. Distinguishing phenotypic characteristics of $V$. breoganii and phenotypically and phylogenetically related Vibrio species

Species: 1, V. breoganii sp. nov. (n=7); 2, V. comitans; 3, V. inusitatus; 4, V. rarus; 5, V. ezurae; 6, V. neonatus; 7, V. halioticoli; 8, V. gallicus; 9, V. superstes. Except for $V$. breoganii, data are from type strains and were obtained in our laboratory. + , Positive; - , negative; $v+$, variable, but type strain is positive (numbers of strains testing positive are in parentheses); $\mathrm{v}-$, variable, but type strain is negative (numbers of strains testing positive are in parentheses). All species are fermentative, sensitive to the vibriostatic agent $\mathrm{O} / 129(150 \mu \mathrm{g})$, non-motile, oxidase- and catalasepositive, require $\mathrm{Na}^{+}$for growth, reduce nitrate, grow in $3 \% \mathrm{NaCl}$ and at $15-30{ }^{\circ} \mathrm{C}$, grow on TCBS, produce alginase, and produce acid from D-glucose and D-mannitol. All species are negative for pigmentation, swarming, growth above $37{ }^{\circ} \mathrm{C}$ and in $<0.5 \% \mathrm{NaCl}$, gas production from D-glucose, arginine dihydrolase, lysine and ornithine decarboxylases, luminescence, hydrolysis of agar, production of amylase, gelatinase and lipase, and acid production from D-sorbitol, L-arabinose and inositol.

\begin{tabular}{|c|c|c|c|c|c|c|c|c|c|}
\hline Characteristic & 1 & 2 & 3 & 4 & 5 & 6 & 7 & 8 & 9 \\
\hline Indole test & - & - & - & + & + & + & + & + & - \\
\hline ONPG test & + & + & - & - & - & - & + & - & - \\
\hline Amygdalin & + & + & + & - & + & - & - & - & + \\
\hline Glycerol & - & - & - & + & - & - & + & - & - \\
\hline D-Ribose & $v-(2)$ & - & - & - & - & - & + & + & + \\
\hline D-Galactose & + & + & - & - & - & + & - & - & + \\
\hline Aesculin & + & + & + & - & - & - & - & - & + \\
\hline Salicin & + & + & + & - & - & - & - & - & + \\
\hline Cellobiose & + & + & + & + & + & - & - & - & + \\
\hline Trehalose & - & - & - & - & - & - & - & - & + \\
\hline Gentiobiose & + & + & + & + & + & - & - & - & + \\
\hline \multicolumn{10}{|l|}{ API ZYM tests: } \\
\hline Esterase (C4) & + & - & - & - & - & - & - & + & - \\
\hline Esterase lipase (C8) & $v+(6)$ & - & - & - & - & + & - & + & - \\
\hline Acid phosphatase & + & - & - & - & - & - & - & - & + \\
\hline Naphthol-AS-BI-phosphohydrolase & + & - & - & - & - & - & - & - & - \\
\hline
\end{tabular}

onies that are $0.3-0.7 \mathrm{~mm}$ in diameter on MA plates after $24 \mathrm{~h}$ incubation at $25^{\circ} \mathrm{C}$. Not luminescent. All strains apart from strain RD 2G5, which forms colonies with a translucent yellow appearance, form opaque, round $(0.7-1.0 \mathrm{~mm}$ diameter), green colonies on TCBS agar. No growth occurs without $\mathrm{NaCl}$ in the culture medium. Mesophilic and chemoorganotrophic. Growth occurs in 1.5-6.0\% NaCl (w/v) and at $4{ }^{\circ} \mathrm{C}$, but not at salinities above $8.0 \% \mathrm{NaCl}$ or above $37{ }^{\circ} \mathrm{C}$. Susceptible to the vibriostatic agent O/129 (150 $\mu$ g per disc); all strains apart from C 5.5 are resistant to ampicillin $(10 \mu \mathrm{g}$ per disc). Negative for arginine dihydrolase, and lysine and ornithine decarboxylases. Ferments glucose without producing gas and positive for oxidase and catalase. Reduces nitrates to nitrites. Indole, urease, Voges-Proskauer, $\mathrm{H}_{2} \mathrm{~S}$, gelatinase, amylase, use of citrate, lipase and DNase tests are all negative. Positive for methyl red, ONPG and alginase activity tests. API ZYM reaction tests are positive for alkaline phosphatase, butyrate esterase (C4), esterase lipase (C8), leucine arylamidase, acid phosphatase, naphthol-AS-BIphosphohydrolase and $N$-acetyl- $\beta$-glucosaminidase. Produces acid from D-xylose, D-galactose, D-fructose, Dmannitol, $N$-acetylglucosamine, amygdalin, aesculin, salicin, cellobiose, maltose, gentiobiose, potassium gluconate and potassium 2-ketogluconate. Does not produce acid from glycerol, erythritol, D-arabinose, L-arabinose, D-adonitol, methyl- $\alpha$-D-xylopyranoside, L-sorbose, L-rhamnose, dulcitol, inositol, D-sorbitol, methyl- $\alpha$-D-mannopyranoside, methyl- $\alpha$ D-glucopyranoside, trehalose, inulin, melezitose, raffinose, xylitol, turanose, D-lyxose, D-tagatose, D-fucose, D-arabitol, Larabitol or potassium 5-ketogluconate.

The type strain RD $15.11^{\mathrm{T}}\left(=\mathrm{CECT} 7222^{\mathrm{T}}=\mathrm{LMG} 23858^{\mathrm{T}}\right.$ ) and six reference strains [RD 2G5 (=CECT $7367=\mathrm{LMG}$ 24484), VB 16.3, C5.5, RD 2B2, C 4.15 and CMJ 13.7] were isolated from the clams Ruditapes decussatus and Ruditapes philippinarum in Galicia, north-west Spain. The DNA $\mathrm{G}+\mathrm{C}$ content of strain RD $15.11^{\mathrm{T}}$ is $44.4 \mathrm{~mol} \%$. Strain RD $15.11^{\mathrm{T}}$ produces acid from melibiose, L-xylose, arbutin, glycogen and D-lactose, but not from sucrose, D-ribose, Dmannose or L-rhamnose.

\section{Acknowledgements}

This work was supported in part by grants AGL2003-09307-C02-01 and AGL2006-13208-C02-01 from the Ministerio de Ciencia y 
Tecnología, and grant PGIDIT04PXIC20001PN from the Xunta de Galicia (Spain). R.B.H. and S. B. acknowledge the Ministerio de Ciencia y Tecnología (Spain) for research fellowships. The research was also supported by the Prime Minister's Services - Federal Office for Scientific, Technical and Cultural Affairs, Belgium. The authors wish to acknowledge Katrien Engelbeen for performing the DNADNA hybridizations.

\section{References}

Beaz Hidalgo, R., Cleenwerck, I., Balboa, S., De Wachter, M., Thompson, F. L., Swings, J., De Vos, P. \& Romalde, J. L. (2008). Diversity of vibrios associated with reared clams in Galicia (NW Spain). Syst Appl Microbiol 31, 215-222.

Cleenwerck, I., Vandemeulebroecke, K., Janssens, D. \& Swings, J. (2002). Re-examination of the genus Acetobacter, with descriptions of Acetobacter cerevisiae sp. nov. and Acetobacter malorum sp. nov. Int J Syst Evol Microbiol 52, 1551-1558.

Ezaki, T., Hashimoto, Y. \& Yabuuchi, E. (1989). Fluorometric deoxyribonucleic acid-deoxyribonucleic acid hybridization in microdilution wells as an alternative to membrane filter hybridization in which radioisotopes are used to determine genetic relatedness among bacterial strains. Int J Syst Bacteriol 39, 224-229.

Farmer, J. J., III (1992). The family Vibrionaceae. In The Prokaryotes: a Handbook on the Biology of Bacteria, 2nd edn, pp. 2938-2951. Edited by A. Balows, H. G. Trüper, M. Dworkin, W. Harder \& K. H. Schleifer. New York: Springer-Verlag.

Gómez-León, J., Villamil, L., Lemos, M. L. \& Novoa, B. (2005). Isolation of Vibrio alginolyticus and Vibrio splendidus from aquacultured carpet shell clam (Ruditapes decussatus) larvae associated with mass mortalities. Appl Environ Microbiol 71, 98-104.

Goris, J., Suzuki, K., De Vos, P., Nakase, T. \& Kersters, K. (1998). Evaluation of a microplate DNA-DNA hybridization method compared with the initial renaturation method. Can J Microbiol 44, 1148-1153.

Hayashi, K., Moriwaki, J., Sawabe, T., Thompson, F. L., Swings, J., Gudkovs, N., Christen, R. \& Ezura, Y. (2003). Vibrio superstes sp. nov., isolated from the gut of Australian abalones Haliotis laevigata and Haliotis rubra. Int J Syst Evol Microbiol 53, 1813-1817.

Heimbrook, M. E., Wang, W. L. \& Campbell, G. (1989). Staining bacterial flagella easily. J Clin Microbiol 27, 2612-2615.

Kueh, C. S. W. \& Chan, K. Y. (1985). Bacteria in bivalve shellfish with special reference to the oyster. J Appl Bacteriol 59, 41-47.

Lemos, M. L., Toranzo, A. E. \& Barja, J. L. (1985). Modified medium for the oxidation-fermentation test in the identification of marine bacteria. Appl Environ Microbiol 49, 1541-1543.

MacFaddin, J. F. (1993). Pruebas Bioquímicas para la Identificación de Bacterias de Importancia Clínica (translation by Médica Panamericana SA). Baltimore, MD: William \& Wilkins (in Spanish).

Mesbah, M., Premachandran, U. \& Whitman, W. B. (1989). Precise measurement of the $\mathrm{G}+\mathrm{C}$ content of deoxyribonucleic acid by highperformance liquid chromatography. Int J Syst Bacteriol 39, 159-167.

Nhung, P. H., Shah, M. M., Ohkusu, K., Noda, M., Hata, H., Sun, X. S., Goto, K., Masaki, T., Miyasaka, J. \& Ezaki, T. (2007). The dnaJ gene as a novel phylogenetic marker for identification of Vibrio species. Syst Appl Microbiol 30, 309-315.

Prado, S. (2006). Microbiota asociada a criaderos de moluscos patogénesis $y$ probiosis. $\mathrm{PhD}$ thesis, Universidad de Santiago de Compostela, Spain.

Prado, S., Romalde, J. L., Montes, J. \& Barja, J. L. (2005). Pathogenic bacteria isolated from disease outbreaks in shellfish hatcheries. First description of Vibrio neptunius as an oyster pathogen. Dis Aquat Organ 67, 209-215.
Pujalte, M.-J., Ortigosa, M., Urdaci, M.-C., Garay, E. \& Grimont, P. A. D. (1993). Vibrio mytili sp. nov., from mussels. Int J Syst Bacteriol 43, 358-362.

Romalde, J. L. \& Toranzo, A. E. (1991). Evaluation of the API $20 \mathrm{E}$ system for the routine diagnosis of the enteric redmouth disease. Bull Eur Assoc Fish Pathol 11, 147-149.

Sawabe, T., Oda, Y., Shiomi, Y. \& Ezura, Y. (1995). Alginate degradation by bacteria isolated from the gut of sea urchins and abalones. Microb Ecol 30, 192-202.

Sawabe, T., Sugimura, I., Ohtsuka, M., Nakano, K., Tajima, K., Ezura, Y. \& Christen, R. (1998). Vibrio halioticoli sp. nov., a non-motile alginolytic marine bacterium isolated from the gut of the abalone Haliotis discus hannai. Int J Syst Bacteriol 48, 573-580.

Sawabe, T., Thompson, F. L., Heyrman, J., Cnockaert, M., Hayashi, K., Tanaka, R., Yoshimizu, M., Hoste, B., Swings, J. \& Ezura, Y. (2002). Fluorescent amplified fragment length polymorphism (FAFLP) and repetitive extragenic palindrome-PCR fingerprinting reveal hostspecific genetic diversity of Vibrio halioticoli-like strains isolated from the gut of Japanese abalone. Appl Environ Microbiol 68, 4140-4144.

Sawabe, T., Setoguchi, N., Inoue, S., Tanaka, R., Ootsubo, M., Yoshimizu, M. \& Ezura, Y. (2003). Acetic acid production of Vibrio halioticoli from alginate: a possible role for establishment of abaloneV. halioticoli association. Aquaculture 219, 671-679.

Sawabe, T., Hayashi, K., Moriwaki, J., Fukui, Y., Thompson, F. L., Swings, J. \& Christen, R. (2004a). Vibrio neonatus sp. nov., and Vibrio ezurae sp. nov. isolated from the gut of Japanese abalones. Syst Appl Microbiol 27, 527-534.

Sawabe, T., Hayashi, K., Moriwaki, J., Thompson, F. L., Swings, J., Potin, P., Christen, R. \& Ezura, Y. (2004b). Vibrio gallicus sp. nov., isolated from the gut of the French abalone Haliotis tuberculata. Int $J$ Syst Evol Microbiol 54, 843-846.

Sawabe, T., Fujimura, Y., Niwa, K. \& Aono, H. (2007a). Vibrio comitans sp. nov., Vibrio rarus sp. nov. and Vibrio inusitatus sp. nov., from the gut of the abalones Haliotis discus discus, $H$. gigantea, $H$. madaka and H. rufescens. Int J Syst Evol Microbiol 57, 916-922.

Sawabe, T., Kita-Tsukamoto, K. \& Thompson, F. L. (2007b). Inferring the evolutionary history of vibrios by means of multilocus sequence analysis. J Bacteriol 189, 7932-7936.

Tamura, K., Dudley, J., Nei, M. \& Kumar, S. (2007). MEGA4: molecular evolutionary genetics analysis (MEGA) software version 4.0. Mol Biol Evol 24, 1596-1599.

Thompson, F. L., Hoste, B., Vandemeulebroecke, K. \& Swings, J. (2001). Genomic diversity amongst Vibrio isolates from different sources determined by fluorescent amplified fragment length polymorphism. Syst Appl Microbiol 24, 520-538.

Thompson, C. C., Thompson, F. L., Vandemeulebroecke, K., Hoste, B., Dawyndt, P. \& Swings, J. (2004). Use of $r e c A$ as an alternative phylogenetic marker in the family Vibrionaceae. Int J Syst Evol Microbiol 54, 919-929.

Thompson, F. L., Gevers, D., Thompson, C. C., Dawyndt, P., Naser, S., Hoste, B., Munn, C. B. \& Swings, J. (2005). Phylogeny and molecular identification of vibrios on the basis of multilocus sequence analysis. Appl Environ Microbiol 71, 5107-5115.

Thompson, C. C., Thompson, F. L., Vicente, A. C. \& Swings, J. (2007). Phylogenetic analysis of vibrios and related species by means of atpA gene sequences. Int J Syst Evol Microbiol 57, 2480-2484.

West, P. A., Brayton, P. R., Bryant, T. N. \& Colwell, R. R. (1986). Numerical taxonomy of vibrios isolated from aquatic environments. Int J Syst Bacteriol 36, 531-543.

Wilson, K. (1987). Preparation of genomic DNA from bacteria. In Current Protocols in Molecular Biology, pp. 2.4.1-2.4.5. Edited by F. M. Ausubel, R. Brent, R. E. Kingston, D. D. Moore, J. G. Seidman, J. A. Smith \& K. Struhl. New York: Green Publishing and Wiley Interscience. 